\title{
Coronavirus, Cohorts, and International Demography
}

Keera Allendorf

Follow this and additional works at: https://knowledgecommons.popcouncil.org/series_pdr_essays-covid How does access to this work benefit you? Let us know!

\section{Recommended Citation}

Allendorf, Keera. "Coronavirus, Cohorts, and International Demography." In Covid-19 and the Global Demographic Research Agenda, edited by Landis MacKellar and Rachel Friedman, 3-7. New York: Population Council, 2021. 


\title{
Coronavirus, Cohorts, and International Demography
}

\author{
KeERA Allendorf
}

IN THE SHORT TERM, the pandemic presents a profound period effect. In 2020, as the novel coronavirus spread and mortality rose, governments closed borders, public events evaporated, and economic hardship skyrocketed. Steep age effects of the pandemic were also rapidly apparent. The risk of dying of Covid-19 is dramatically higher among the elderly and especially low among young children.

Yet, when asked to consider how Covid-19 may shape future demographic research needs, my mind kept turning to cohort effects, the diagonal axis of demography's time trio. I fear the pandemic will adversely shape the composition and research interests of cohorts of future demographers. Specifically, the pandemic may make upcoming cohorts of demographers more American and less likely to engage in international research, especially fieldwork. In turn, future demographic research may become less comparative and more US-focused.

Cohorts of demographers who experience the pandemic during graduate school may be pushed toward solely quantitative, US-based dissertations. US-origin students who study populations outside the US often complete mixed-methods dissertations with fieldwork components. The pandemic likely forced advanced students to stop fieldwork early and cancel upcoming fieldwork plans. Beginning graduate students may well decide planning and completing international fieldwork is too risky or practically impossible for the next few years. International travel funds and fellowships appear to be disappearing as budgets contract. Pre-dissertation trips to assess potential field sites may never occur. And, years-long processes of taking language classes may seem like a waste of precious time. Instead, graduate students may turn to the safer route of analyzing survey data collected in the US. Once solidified, this approach may persist long past graduate school.

Younger cohorts of Americans who may become demographers farther into the future are likely missing experiences that would motivate and pre-

Keera Allendorf, Department of Sociology, Indiana University.

POPULATION AND DEVELOPMENT REVIEW I ESSAYS (FEBRUARY 2021) 
pare them to embark on international fieldwork later in life. The pandemic put many study-abroad trips, which undergraduates undertake within a brief window, on hold or out of financial reach. Entry-level jobs in organizations where college graduates gain international experience disappeared or shrank with pandemic-induced travel freezes and budget cuts. The pandemic motivated many high school students to take gap years before college, but these breaks do not feature international travel.

My fears are based on considering the counterfactuals of my own life as an emerging demographer. A foundational experience of my research is dissertation fieldwork undertaken in 2007-08 in a village in India. That academic year depended on long-term planning, funding, and language classes, as well as an extra year of school spent waiting for a research visa, from 2002-07. Many experiences before graduate school were also instrumental. Working at the International Center for Research on Women in 2000-02, I made my first trip to India and learned of the existence of demography. Earlier, in 1998, a study-abroad program in Nepal provided inspiration for my dissertation research questions, as well as language and field experience. And as a teenager, my interest in the region was galvanized by my sister's time in Nepal as a Peace Corps Volunteer in 1992-94. If a pandemic had occurred in 1992, 1998, 2000, or any point from 2002-08, I may never have gone to India for my dissertation and my research agenda may well have turned to the US.

Reflections on experiences of my colleagues who are not of US-origin suggests upcoming cohorts of demographers may also become more American. Since demography is not a staple of secondary schooling many of us encounter the discipline by accident as undergraduates or even graduate students. As a small field, demographers tend to be trained in a small number of universities, many of which are in the US. Many young people only encounter demography and become demographers if they attend one of these universities. With the pandemic, these universities are not sending staff on trips to recruit international students. Further, many prospective students may choose to stay close to home in the uncertain context of the pandemic or no longer have the finances to support schooling abroad. Inhospitable immigration policies of the US, which worsened in the pandemic, will also push international students away from American universities. And, for those who are farther along, the pandemic-induced collapse of the job market may be even more devastating for those who are not American citizens. These newly minted demographers require immediate academic jobs to stay in the US and, in some cases, stay in demography.

Such cohort effects could reduce the quality of demographic research and theory for years to come. A scarcity of fieldwork will limit our understanding of demographic processes on the ground and our ability to build explanations of how and why these processes vary and change. Two decades ago, Knodel (1997) laid out a compelling case for the use of qualitative 
methods for demographers, which remains equally relevant today. As he noted, when demographers themselves use qualitative methods the resulting research is especially dense with demographic insights.

I want to highlight other longer-term, more hidden benefits of such work, though. Ethnographic observation and collection of less structured interviews allow-even force-researchers to be highly involved with the populations they study (Axinn and Pearce 2006). Such involvement leads to deeper understanding, which is invaluable when demographers study populations to which they do not belong. Reading is vital, but there is a more visceral understanding when reading is combined with on-the-ground experience. Such understanding stimulates new research questions and hypotheses, as well as better measures and modeling, when we use quantitative methods and data, sometimes years later. For instance, what I encountered during fieldwork resonated so strongly with developmental idealism theory that I devoted much of the last decade to assessing the influence of developmental idealism on demographic behavior.

One reason fieldwork is so generative is the analytical power of comparison. The deeper knowledge gained through fieldwork comes in part from comparison to other populations the researcher knows from personal experience. As social scientists we are informal ethnographers of the populations we live in-drawing inspiration and understanding from our own lives and those around us. Fieldwork inevitably includes ruminating on how and why life in the study population differs from home or a "reference" population. Like learning another language, such comparisons enable richer understanding of both contexts. It was only through learning to use postpositions in Nepali that I really understood prepositions in English. Similarly, comparisons of my Indian fieldwork to interactions with my husband's family in Greece fueled insights into family demography. Parallels with Indian interviews helped me quickly grasp my Greek grandmother-in-law's story of her arranged marriage. Yet, seeing this senior woman do all the cooking made me rethink generational dynamics of joint families.

Fieldwork is not the only way demographers become involved with other populations, though. Living and working or attending school in another country is another way to gain such involvement. This link is one reason it is important future cohorts include demographers who are not from the US. Their ability to compare their current context to where they used to live also provides unique demographic insights and inspiration. When asked by a journalist about the motivation for work on Indian one-child families, Sonalde Desai explained, "There is interesting work in the US on ways in which women combine career and motherhood by limiting themselves to a single child. I was surprised to see the number of people I saw around me [in the US] with a single child and wondered if the same processes might be operating in India" (Lopez 2020). 
While I am concerned about adverse cohort effects, I am also heartened by new opportunities for international research presented by the pandemic. First, the normalization of online meetings and webinars may facilitate international exchanges and collaborations. We are now adapted to traversing distances virtually. Seminar series and conferences may include occasional webinars with speakers "zooming in" from afar even when most events are in-person. The new practice of making recordings, as well as data and code, available online might even send demography into the hands (and ears) of future demographers located anywhere with a smartphone and an internet connection.

Second, indirect effects of the pandemic may improve the balance of international comparisons. The surging Black Lives Matter movement in the US seems to have been aided in part by unsettling caused by the pandemic. There is new recognition of the importance of Black scholars and scholarship on race in demography and other fields. This heightened energy around diversity may extend beyond racial hierarchies within the US to international hierarchies as well. While demography is more international than many disciplines, there is a lingering US orientation. Publishing on India and Nepal, reviewers often exhort me to justify the study location and discuss the relevance of the findings to the US. By contrast, the importance of the US is often taken for granted and authors of US studies are not usually pushed to address the relevance of their findings to other places.

I hope a broad view of diversity motivates us to decenter the US, rather than abandoning comparisons. Pressure from reviewers to make comparisons benefited my research. Considering precisely how and why processes we are studying in one population differ from those in others is exactly the type of theory-building work demographers should engage in. It is the US orientation that could be rebalanced. Comparisons to the US are often useful, but in many cases comparisons to other populations are more instructive. And, even when studying the US, we should consider how our findings fit into theories of how and why demographic processes unfold in a broader global landscape.

Before closing, I want to address two incongruities in these reflections. Ironically, while pointing to the value of decentering the US, I focused these reflections on the US. This orientation is no accident. It is US demography that seems most at risk of these adverse cohort effects and most in need of international perspectives. Americans must go a long way to gain substantial international experience and many never do so. Further, many demographers working and training in the US are located within sociology departments. Sociology's strong US focus seeps into demography.

The US also plays an outsize role in demography as the base of many demographers, as well as leading demography journals. A comparison of the relative size of professional associations provides a rough measure of this 
outsize role. In 2021, the Population Association of America (PAA) is nearly twice as large as the International Union for the Scientific Study of Population (IUSSP) and four times larger than the European Association for Population Studies (EAPS). According to their respective websites, PAA has over 3,000 members, IUSSP's membership stands at 1,600, and EAPS has just under 700 .

Finally, while I hope our tradition of an international, comparative demography persists well beyond the pandemic, I also want to emphasize that populations do not map neatly onto national borders. Often, the farther from home we go, the more different things are, and the more we learn. We do not always have to venture to another country though. Even in the US, traveling to another region, or sometimes just down the street, can enmesh one in a different demographic reality.

\section{References}

Axinn, William G. and Lisa D. Pearce. 2006. Mixed Method Data Collection Strategies. Cambridge: Cambridge University Press.

Knodel, John. 1997. "A case for nonanthropological qualitative methods for demographers," Population and Development Review 23(4): 847-853.

Lopez, Rachel. 2020. "How one-child families are transforming India," Hindustan Times, 29 February. Accessed October 16, 2020. https://www.hindustantimes.com/more-lifestyle/howone-child-families-are-transforming-india/story-ATc9DORXLK1RS3fBXCub4K.html. 